\title{
PKM Tata Busana di Desa Suka Damai Kecamatan Ujungbatu Rokan Hulu
}

\author{
Batdal Niati*1, Nurul Afifah ${ }^{2}$ \\ Pendidikan Bahasa Inggris ${ }^{1}$, Pendidikan Biologi², Fakultas Keguruan dan Ilmu Pendidikan, Universitas \\ Pasir Pengaraian \\ e-mail: $\underline{\text { batdaln@gmail.com*1 }} \underline{\text { nurulafifah.upp@gmail.com }}{ }^{2}$
}

\begin{abstract}
The community partnership program (PKM) had done at Sukadamai Village Ujungbatu District Rokan Hulu Regency Riau Province. Most of the Societies work as oil palm factory workers who earn below the average MSE (minimum wage for performance) and lack specific skills to supplement their incomes. For this reason, community empowerment is needed to improve family welfare. This PKM is aimed at housewives in Sukadamai Village. This PKM is implemented in the form of counseling, training, and business assistance. Counseling is given to add partners' insights about fashion and entrepreneurship. Procurement of tools and raw materials is given to support business activities. The fashion training provided was sewing training, pattern design, and embroidery. Business assistance had been carried out in the form of assistance with service promotion, financial records and marketing strategies. The result of this PKM is that women had the expertise to design clothing patterns, sewing, and embroidering and forming UMKM in the fashion sector in Sukadamai Village.
\end{abstract}

Keywords: Counseling, Training, Clothing; Sewing, Designing, Embroidering

\begin{abstract}
Abstrak
Program kemitraan masyarakat (PKM) dilakukan di Desa Sukadamai Kecamatan Ujungbatu Kabupaten Rokan Hulu Provinsi Riau. Sebagaian besar masyarakat di desa ini berprofesi sebagai buruh pabrik sawit yang berpenghasilan dibawah rata-rata UMK (Upah minimum kinerja) dan belum adanya keterampilan (skill) khusus untuk menambah penghasilan. Untuk itu perlu adanya pemberdayaan masayrakat untuk meningkatkan kesejahteraan keluarga. Kegiatan pengabdian ini ditujukan untuk ibu-ibu rumah tangga Desa Sukadamai. PKM ini dilaksanakan dalam bentuk penyuluhan, pelatihan, dan pendampingan usaha. Penyuluhan yang diberikan untuk menambah wawasan mitra tentang tata busana (fashion) dan kewirausahaan. Pengadaan alat dan bahan baku diberikan untuk mendukung kegiatan usaha. Pelatihan tata busana yang diberikan yaitu pelatihan menjahit, mendesain pola, dan membordir. Pendampingan usaha yang telah dilakukan dalam bentuk bantuan promosi jasa, pencatatan keuangan dan strategi pemasaran. Hasil kegiatan pengabdian ini adalah ibu-ibu telah memiliki keahlian mendesain pola pakaian, menjahit, dan membordir dan membentuk UMKM bidang tata busana di Desa Sukadamai.
\end{abstract}

Kata kunci: Penyuluhan, Pelatihan, Tata Busana; Menjahit, Mendesain Pola, Membordir

\section{PENDAHULUAN}

Desa suka damai adalah sebuah desa yang terletak di provinsi Riau. Desa ini merupakan salah satu desa di kecamatan Ujungbatu kabupaten Rokan Hulu. Desa suka damai memiliki luas wilayah 1.380 Ha dengan jumlah penduduk 7.762 jiwa dan 1.655 keluarga (data desa suka damai, 2018). Desa suka damai memiliki 6 dusun dan 30 Rw. Pada umumnya mata pencaharian masyarakat Desa Suka damai bersumber dari kebun sawit. Sebagian penduduk laki-laki didesa ini berprofesi sebagai petani sawit dan sebagian yang lain sebagia buruh pabrik sawit yang ada didesa suka damai. Sementara itu, penduduk perempuan sebagai ibu rumah tangga.

Tidak semua warga memiliki kebun sawit. Warga yang tidak memiliki kebun sawit bekerja sebagai buruh pabrik. Mereka hanya bekerja satu kali satu minggu dikarenakan giliran (shift system) di pabrik. Tugas mereka dipabrik adalah sebagai tukang bongkar kelapa sawit dari Track untuk dimasukkan dan diolah didalam mesin pengolah. Penghasilan yang mereka peroleh berkisar anatara Rp. 600.000-800.000/bulan. Untuk itu, mereka masih harus mencari penghasilan tambahan, misalnya dengan menjadi buruh panen sawit tetangganya. Pengahasilan 
yang mereka dapat Rp. 200.000 / kapling (2ha). Jadi, rata-rata penghasilan masyarakat yang berprofesi sebagi buruh pabrik yaitu Rp. 800.000-1.000.000. Ibu rumah tangga yang memiliki suami buruh pabrik turut membantu suaminya menambah penghasilan keluarga. Biasanya, mereka bekerja sambilan sebagai buruh pasar dengan mengupas bawang merah. Rata/rata upah yang mereka terima sehari hanya Rp. 15.000/ Karung. Jika digabung penghasilan suami dan istri berkisar antara Rp. 1.000.000 - 1.400.000/Bulan. Selanjutnya, 30\% warga memiliki pendidikan terakhir SMA, sedangkan 70\% dibawah tingkat SMA (sumber: Data Desa Sukadamai Kabupaten Rokan Hulu tahun 2018). Hal ini juga menjadi faktor sulitnya warga untuk bekerja dikantor/instasi ditambah kurangnya skill/keahlian yang dimiliki warga. Sehingga, untuk menambah penghasilan keluarga, mereka bekerja sebagai buruh pabrik dan buruh pasar.

Berdasarkan informasi yang diperoleh oleh tim pengusul, sudah ada kegiatan penyuluhan dan pelatihan yang diberikan oleh Disnaker kabupaten Rokan Hulu tahun 2015 yaitu pelatihan menjahit dan kursus komputer. Namun, kegiatan ini hanya diikuti oleh delapan orang ibu rumah tangga karena terbatasnya kuota. Hasil pelatihan menjahit maupun kursus komputer tidak dapat diaplikasikan secara maksimal dan optimal dikarenakan kegiatannya hanya pelatihan, tidak adanya pengadaan alat dan bahan baku bagi peserta untuk berlatih lebih lanjut serta tidak adanya kelanjutan (follow up) kegiatan tersebut berupa pendampingan berwirausaha. Sehingga keterampilan yang diperoleh hanya sebatas pengalaman saja.

Hal diatas yang memacu pengusul untuk mengadakan kegiatan program kemitraan masyarakat dalam rangka pemberdayaan dan pengembangan skill masyarakat berupa pelatihan, pendampingan, dan manajemen usaha dibidang tata busana / penjahitan untuk membantu menumbuhkan skill, menambah penghasilan, dan mendirikan usaha dan menciptakan lapangan kerja di desa suka damai. Kegiatan yang dilakukan berbasis pada kearifan lokal, yaitu melayu. Tim pengusul memfokuskan pada produksi baju melayu, sehingga diharapkan dapat dikembangkan menjadi kampung tata busana atau sentra konveksi busana melayu Rokan Hulu Riau.

Di Riau, khususnya kabupaten Rokan Hulu, masyarakat wajib sehari/seminggu berbusana melayu baik di sekolah, kantor mapun kampus. Anak sekolah, guru, pegawai kantor, mahasiswa dan dosen butuh baju melayu. Sehingga, pasar tata busana yang akan dibidik dari hasil kegiatan ini dimulai dari sekolah dasar, menengah, atas, kantor pemerintah dan swasta, serta universitas. Usaha tata busana akan selalu memiliki ruang dan peluang ditengah masyarakat.

Tata busana berkaitan erat dengan perempuan yaitu cantik dan rapi. Maka dari itu, tata busana berhubungan dengan tata rias. Tata busana tentang cantik dan rapi untuk pakaian. Sedangkan tata rias tentang cantik dan rapi untuk penampilan wajah. Menurut Fitridawati Soehardi \& Dwi Vita Lestari Soehardi (2019), Tata rias merupakan cara atau usaha seseorang untuk mempercantik diri khususnya pada bagaian muka atau wajah. Tata rias wajah merupakan suatu seni yang bertujuan untuk mempercantik wajah dengan menonjolkan bagian - bagian yang sudah indah dan menyamarkan atau menutupi kekurangan pada wajah.

Tata busana merupakan istilah untuk menyebutkan sebuah konsep/nama dari kegiatan yang berhubungan dengan pakaian. Tata busana adalah menata atau merancang pakaian serta pernak perniknya. Menurut (Ernawati, 2008) tata busana adalah merancang pakaian dan perlengkapannya yang menggambarkan seseorang baik laki-laki maupun perempuan.

Kegiatan, penelitian maupun pengabdian telah banyak dilakukan diantaranya (Armaini, 2015) tentang kegiatan pengabdian kewirausahaan tata busana yang dilakukan di Medan. Kegiatan tersebut sukses, masyarakat banyak mendapat keuntungan dari kegiatan tersebut. Selain skill mereka mendapat penghasilan tambahan. (Noorfitrihana, 2015), (Sawitri, 2018) juga melakukan pengabdian tentang tata busana. Mereka berhasil membantu perekonomian wilayah sasaran menjadi lebih baik.

Oleh sebab itu, tim pengabdi mencoba melakukan pengabdian di desa suka damai. Sasaran kegiatan tata busana ini yaitu kelompok ibu rumah tangga. Untuk meningkatkan kemandirian ekonomi atau menambah penghasilan. Kegiatan tata busana terdiri dari pelatihan dan penyuluhan. Menurut (Fitridawati Soehardi \& Dwi Vita Lestari Soehardi, 2019), pelatihan (training) adalah suatu proses pendidikan jangka pendek yang mempergunakan prosedur 
sistematis dan terorganisir mempelajari pengetahuan dan keterampilan teknis dalam tujuan yang terbatas. Dengan demikian istilah pelatihan ditunjukan pada pelaksanaan untuk meningkatkan pengetahuan dan keterampilan teknis.

Ada beberapa kegiatan tata busana yang dilakukan antara lain pertama adalah penyuluhan tentang wirausaha. Kegiatan ini bertujuan untuk penanaman dan perubahan pola fikir tentang wirausaha. Masyarakat diberi pemahaman bahwa salah satu cara untuk memiliki kemandirian ekonomi yaitu memiliki skill. Skill yang terbaik untuk ibu rumah tangga yaitu keterampilan tata busana. Kegiatan selanjutnya yaitu pelatihan menjahit dasar, membuat pola, dan membordir. Keempat skill ini adalah hal berbeda. Jika ibu rumah tangga memiliki semuanya maka mereka tidak perlu khawatir tentang ekonomi keluarga dan mereka bisa melakukannya dirumah dengan membuka usaha dirumah. Kegiatana selanjutnya yaitu pendampingan pembuatan produk. Tim pengususl mendampingi dalam proses produksi. Terakhir yaitu pengembangan usaha. Ada 6 ibu-ibu rumah tangga yang mengikuti kegiatan tata busana. Mereka merupakan perwakilan dari setiap RW di Desa Suka Damai. Ibu-ibu yang telah dilatih, dapat mengajarkan atau menularkan ilmu yang diperoleh kepada ibu-ibu yang lain agar dapat bersama-sama mengembangkan usaha.

Ada beberapa lingkungan yang menunjang kegiatan ini, diantaranya aspek lingkungan, aspek produktifitas dan aspek aset. Dari aspek lingkungan, lokasi desa suka damai khusunya RW 004 dekat dengan pasar dan beberapa sekolah diantaranya 2 PAUD, 2 SD, 2 SMP. Lokasi ini menguntungkan untuk usaha konveksi seragam formal dan melayu. Dari apsek produktifitas, ibu rumah tangga memiliki waktu yang sangat luang dan mereka masih memiliki usia produktif. Dari aspek aset, adanya ruang yang luas untuk digunakan sebagai tempat penyuluhan, pelatihan dan pendampingan menjahit, mendesai pola, dan memobordir.

Berdasarkan semua informasi yang dihadapi mitra yaitu Belum produktif secara ekonomi. Penghasilan keluarga berikisar Rp. 1.400.000/bulan dibawah rata-rata UMK kabupaten Rokan hulu, Mitra tidak memiliki keterampilan atau keahlian khusus dan Desa mitra belum memiliki produk unggulan. Maka pengusul melakukan kegiatan tata busana dapat membantu mengatasi permasalahan yang dihadapi oleh mitra.

\section{METODE}

Pada bagian metode penerapan, uraikanlah dengan jelas dan padat metode yang digunakan untuk mencapai tujuan yang telah dicanangkan dalam kegiatan pengabdian. Hasil pengabdian itu harus dapat diukur dan penulis diminta menjelaskan alat ukur yang dipakai, baik secara deskriptif maupun kualitatif. Jelaskan cara mengukur tingkat ketercapaian keberhasilan kegiatan pengabdian. Tingkat ketercapaian dapat dilihat dari sisi perubahan sikap, sosial budaya, dan ekonomi masyarakat sasaran.

Dalam pelaksanaan PKM metode yang digunakan adalah Metode kombinasi teori dan aplikasi. Kegiatan ini dilaksanakan melalui tiga tahapan yaitu: (1) tahap perencaan (plan), (2) tahap pelaksanaan (do), dan (3) tahap refleksi (see), (Lewis, 2002). Adapun uraian tugas dan peran dari Tim pengusul yang mengacu pada metode lesson study tersebut, dapat diuraikan sebagai berikut:

\section{(1) Tahap 1 : Perencanaan (Plan)}

Tim pengusul melakukan sejumlah perencana kegiatan PKM yaitu berupa penyusunan materi kegiatan PKM yang dilakukan oleh ketua, anggota pengusul dan empat calon trainer yaitu mentor wirausaha dan mentor penjahit, mentor desain pola dan mentor bordir (enterpreneur trainer dan taylor trainer). 
(2) Tahap 2. Pelaksanaan (Do)

Pelaksanaan kegiatan PKM yaitu;

\section{a. Workshop}

Workshop akan dilakukan pada awal kegiatan PKM. Kegiatan ini berupa workshop penanaman komitmen berwirausaha.

\section{b. Pelatihan}

Kegiatan pelatihan ada tiga yaitu pelatihan menjahit, mendesain pola, dan membordir.

1) Menjahit

Menjahit merupakan sebuah tindakan dalam menyambung kain sesuai pola yang ditentukan berdasarkan ukuran. (Ramadani \& Novrita, 2019) menyebut menjahit menggunakan jarum dan benang, dapat pula dilakukan dengan tangan atau mesin jahit. (Syafri, 2007) mendefinisikan seseorang yang pandai menjahit disebut penjahit. Taylor untuk penjahit laku-laki dan modeste untuk penjahit perempuan.

Pelatihan menjahit diberikan oleh tim pengusul dan akan dilakukan empat hari/ minggu selama tujuh minggu pelaksanaan. Artinya, mitra dilatih menjahit selama 28 kali pertemuan.

2) Mendesain pola

(Syafri, 2007) menyatakan desain pola merupakan kegiatan yang sulit dan membutuhkan kehati-hatian dan konsentrasi tingkat tingggi. Hal ini berkaitan dengan ukuran (angka) baik dalambentuk penjumlahan, pengurangan, perkalian dan pembagian. Jika tidak hati-hati mengakibatkan salah pola/ salah gunting yang akhirnya salah jahit sehingga tidak nyaman bahkan tidak layak untuk dipakai. Pelatihan ini diberikan oleh tim pengusul. Kegiatan ini akan dilakukan empat hari/minggu selama tujuh minggu pelaksanaan. Artinya, mitra dilatih selama 28 kali pertemuan.

3) Membordir

Menurut (Poespa, 2005), membordir adalah hiasan yang direkat dengan jarum dan benang diatas kain/pola baju yang akan digunakan. Hiasan dapat berupa benang sulaman, potongan logam, mutiara, payet, dan manik-manik. Border yang menggunakan benang sulaman menggunakan mesin border untuk membuatnya. (Nurdhani, Desak Putu Agung, 2016), menyebut bahwa Butuh keahlian, kehati-hatian dan konsentrasi membuatnya. Hal ini wajib membuat hiasan sesuai pola yang diinginkan. Selain itu, (Budiastuti, 2013) mengatakan bahwa hiasan border yang menggunakan selain benang sulaman dapat membuat hiasan menggunakan jarum, benang dan direkat dengan tangan. Kegiatan ini diberikan oleh tim dan trainer dan akan dilakukan empat hari/minggu selama tujuh minggu pelaksanaan. Artinya, mitra akan dilatih selama 28 kali pertemuan.

\section{c. Pendampingan Usaha}

Setelah pelatihan, mitra akan diberi bantuan peralatan dan bahan baku untuk mulai membuka usaha. Kemudian, tim dan trainer dibidang kewirausahaan memberi pelatihan mengelola/ menej usaha secara tepat agar mendapat penghasilan yang banyak, serta memberi pendampingan kepada mitra dalam menjalankan usahanya. Pendampingan ini diberikan selama empat minggu (satu bulan).

Untuk mengkur tingkat pemahaman peserta, dilakukan interview dan survey/observasi selama kegiatan menggunakan indicator penilaian yaitu Sebelum dan sesudah kegiatan menjahit, pengenalan mesin, alat-alat mesin, fungsi bagian 
mesin, dan perawatan. Indicator penilaian sebelum dan sesudah mendesain pola yaitu mendesain pola, menentukan ukuran, jenis dan model desain. Indicator penilaian sebelum dan sesudah kegiatan membordir yaitu pengenalan mesin border, penggunaan mesin, dan perawatan mesin border.

\section{HASIL DAN PEMBAHASAN}

Pada kegiatan pertama, tim pelaksana mengadakan workshop komitmen berwirausaha jasa tentang tata busana yang diikuti oleh 22 orang ibu-ibu. Hasilnya hanya 10 ibu-ibu yang siap dan komitmen mengikuti kegiatan. Selanjutnya adalah kegiatan pelatihan pertama yang dilakukan yaitu pelatihan mendesain pola baju. Pelatihan ini dilakukan selama 2 bulan dengan durasi 4 kali / 1 minggu. Dalam tahap ini, banyak kegiatan yang dilakukan. Pertama, tim melatih peserta untuk mengenal ukuran (meteran).

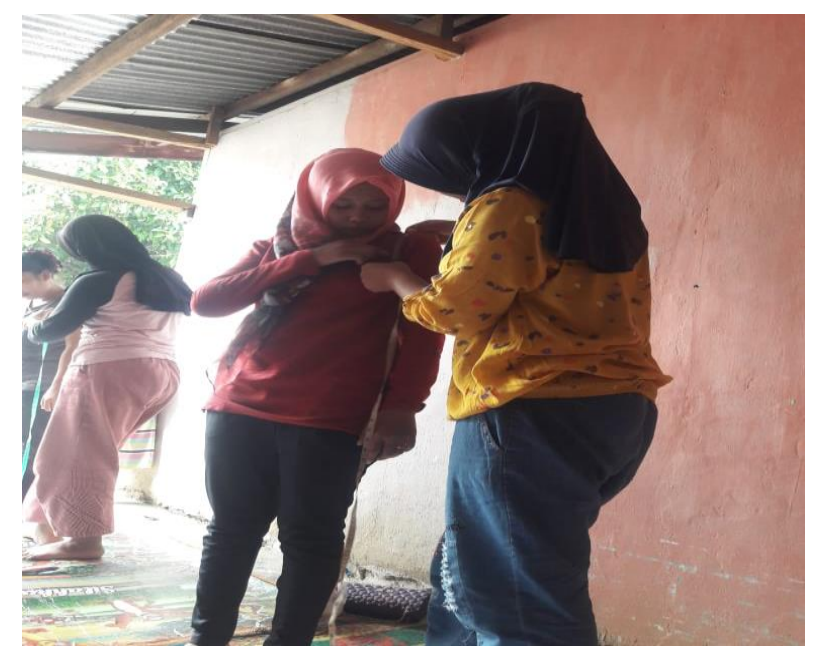

Gambar 1. Penentuan ukuran untuk pembuatan pola

Selanjutnya, mencoba mengukur badan masing-masing, mengukur badan teman, dan badan anak. Tujuannya adalah agar peserta mampu membuat dan membagi ukuran nantinya diatas pola/kain yang akan digunakan. Kegiatan ini dilakukan selama 4 pertemuan / 1 minggu.

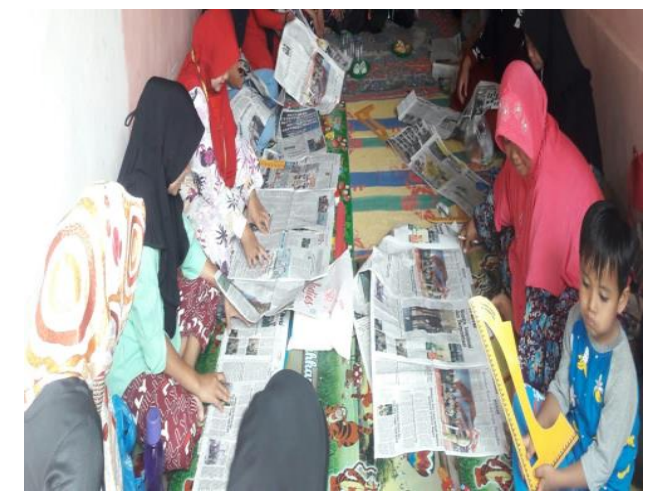

Gambar 2. Pola baju diatas bahan bekas

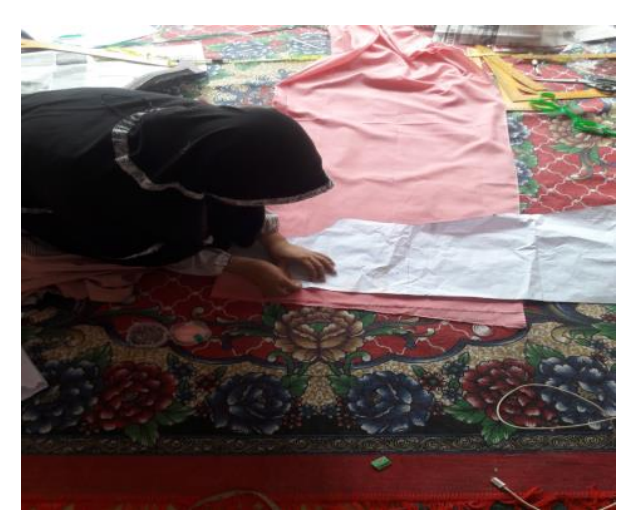

Ganbar 3. Menggunting pola 
Kedua, peserta dilatih untuk membuat pola baju dan rok, gamis ibu-ibu, baju dan rok anak perempuan dan gamis anak perempuan diatas Koran bekas. Kegiatan pembuatan pola ini memerlukan w]aktu selama 2 minggu atau 8 pertemuan. Selanjutnya, ibu-ibu diberi feedback/ soal untuk meningkatkan kemahiran mereka dalam desain pola.

Setelah ibu-ibu menyelesaikan pembuatan semua tipe pola, kegiatan selanjutnya yaitu membuat pola baju dengan menggunakan bahan baju praktik. Kegiatan ini dilakukan selama dua minggu/ 8 pertemuan.

Setelah ibu-ibu mahir membuat dan menggunting kain, kegiatan selanjutnya yaitu pelatihan menjahit. Tim dan trainer melatih ibu-ibu menjahit. Kegiatan ini dilaksanakan selama 15 pertemuan/ 8 Jam atau 4 minggu.

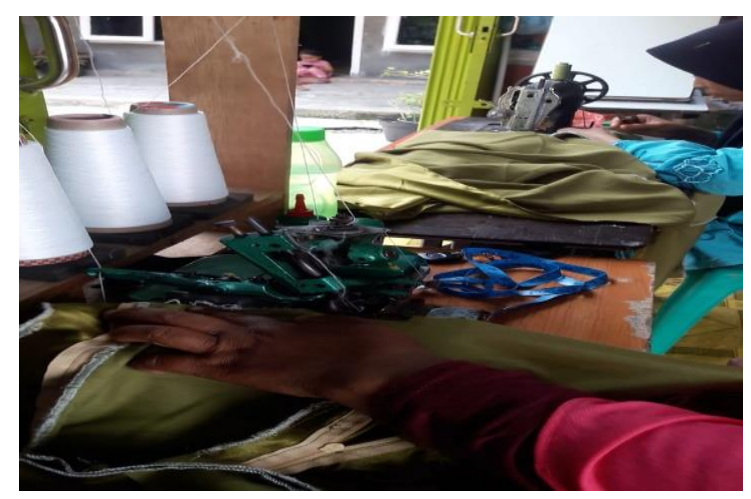

Gambar 4. Penggunaan Mesin Obras

Pelatihan Kegiatan mejahit dimulai dari pengenalan mesin jahit dan mesin obras. Mesin jahit dan mesin obras yang digunakan yaitu mesin yang disewa oleh tim pelaksana dan mesin jahit yang disediakan oleh ibu kades desa suka damai. Selama kegiatan berlangsung, Ibu-ibu diminta untuk mencoba menggunakan / mengoperasikan mesin jahit dan mesin obras.

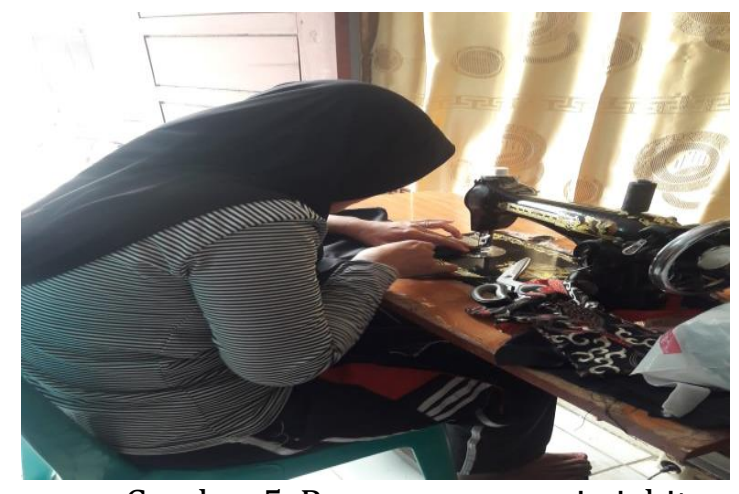

Gambar 5. Penggunaan mesin jahit

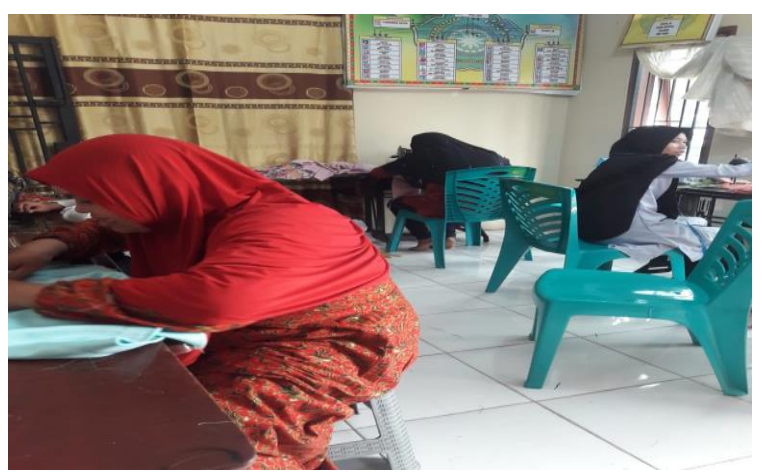

Gambar 6. Menjahit baju dan Rok Melayu

Tahap selanjutnya yaitu menjahit koran. Tujuannya adalah untuk melihat hasil jahitan, ketepatan benang kusut atau tidak, dan ketepatan pemasangan skoci. Kegiatan pengenalan ini dilakukan selama dua pertemuan. Selanjutnya, ibu-ibu dilatih terus menerus untuk menjahit pola baju yang dimulai dari pola baju anak-anak. Menjahit pola ini dilakukan selama 4 pertemuan/ 4 hari yang berdurasi 8 jam/hari. Kemudian, ibu-ibu berlatih untuk mejahit pola baju perempuan selama 4 pertemuan/ 4 hari yang berdurasi 8 jam/hari. 


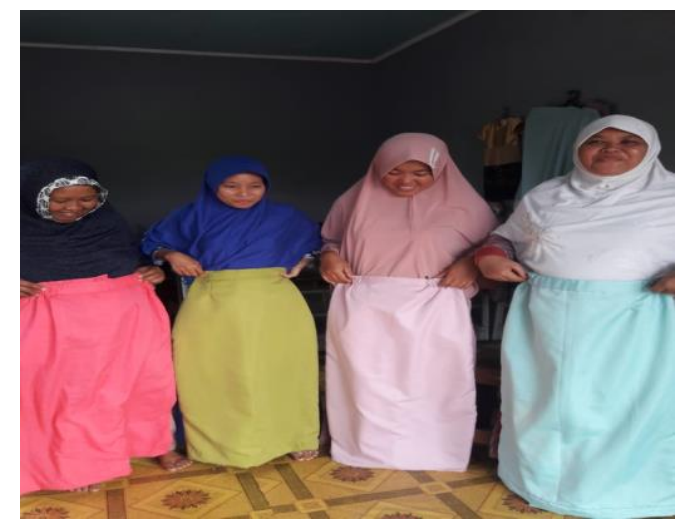

Gambar 7. Hasil Karya Jahitan

Setelah ibu-ibu mengobras kain, selanjutnya yaitu menjahit. Proses menjahit baju dimulai dari memasang resleting (resleting jepang), menjahit lengan, menjahit ketiak dan leher, dan menautkan/menjahit keseluruhan bagian baju. Sedangkan menjahit rok dimulai dari menjahit resleting, menjahit kantong, saku, menjahit pinggang biasa atau pinggang karet. Demikian pula cara untuk menjahit baju dan rok anak perempuan. Menjahit gamis/gaun dimulai dari menjahit resleting atau menjahit lubang kancing, menjahit lengan, menjahit kantonng/saku, dan menautkan/menjahit keseluruhan gamis/gaun. Demikian pula cara untuk menjahit gamis/gaun anak perempuan. Kegiatan terus dilanjutkan sampai ibu-ibu bias menghasilkan baju/rok sesuai pola.

Setelah ibu-ibu bisa mendesain pola dan menjahit, kegiatan selanjutnya yaitu pelatihan membordir. Kegiatan ini dilakukan selama 1 bulan.

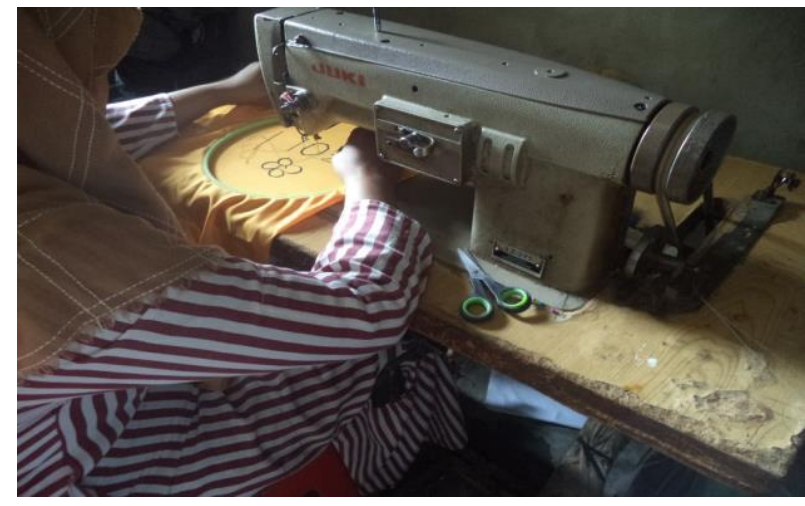

Gambar 8. Membordir Dasar

Tahapannya yaitu pengenalan mesin border, penggunaan/pengoperasian mesin, membordir dasar dan membordir lanjutan.

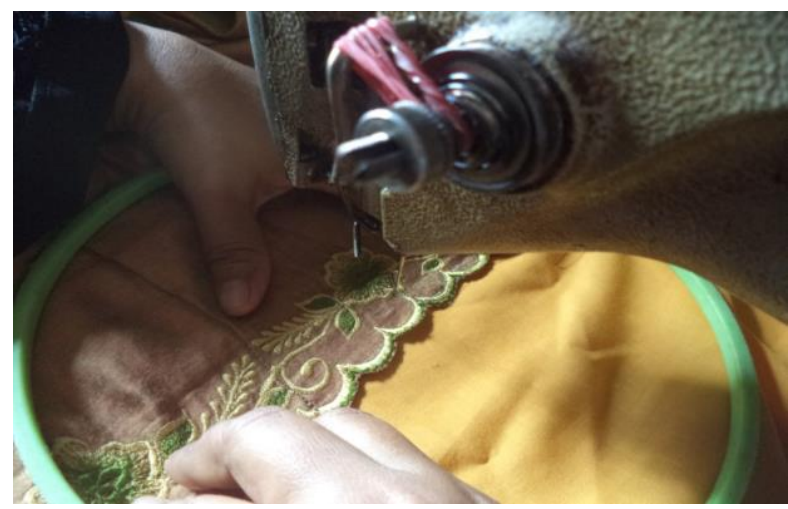

Gambar. 9. Membordir Lanjutan 
Kegiatan membordir dilakukan dimulai dari pengenalan mesin, membordir dasar satu dimensi hingga membordir timbul. Kegiatan ini terus berlanjut sampai hasil bordir rapi dan layak untuk dipamerkan.

Setelah ibu-ibu berlatih mendesain pola, menjahit dan membordir, kegiatan selanjutnya adalah pendampingan usaha. Tahapan yang dilakukan yaitu tim memberikan bantuan kepada Ibu-ibu berupa peralatan menjahit. Selanjutnya ibu-ibu dilatih untuk mempromosikan jasa nya secara offline dan online. Tim terus mendampingi dan mengawasi perkembangan usaha bidang jasa ibu-ibu rumah tangga di desa suka damai.

\section{KESIMPULAN}

Banyak hasil yang dicapai selama kegiatan yang berlangsung yaitu;

1. Mitra memiliki peningkatan motivasi usaha

2. Mitra memiliki keterampilan menjahit, mendesain pola, membordir, penambahan asset usaha. Pengasahan keterampilan tersebut perlu dilakukan terus menerus sehingga produk hasil yang diperoleh terus meningkat, sehingga akan memeprluas jaringan konsumen jasa.

Pendampingan usaha harus tetap dilakukan agar tetap menjaga konsistensi ibu-ibu dalam berwirausaha. Monitoring dan sharing tetap dilakukan untuk membahas masalah yang dihadapi mitra dalam menjalankan usaha bidang jasa tersebut.

\section{UCAPAN TERIMA KASIH}

Terima kasih khusus kepada DRPM Kemenristekdikti yang telah mendukung dan mendanai PKM ini. Terima kasih kepada LPPM Universitas Pasir Pengaraian yang telah memfasilitasi. Terima kasih juga kepada Kepala Desa dan Staff dan ibu-ibu rumah tangga Desa Suka Damai kecamatan Ujungbatu Rokan Hulu yang telah membantu dan berpartisipasi selama kegiatan.

\section{DAFTAR PUSTAKA}

Armaini, R. (2015). IbM Usaha Penjahit Busana Wanita dalam Pembuatan Aksesoris dari Limbah Kain Perca. Jurnal Pengabdian Kepada Masyarajat.

Budiastuti, E. (2013). Teknik Bordir Sasak. Jurnal Ilmiah WUNY. https://doi.org/10.21831/jwuny.v15i1.3532

data desa suka damai. (2018).

Ernawati. (2008). Tata Busana. Direktorat Pembinaan Sekolah Menengah Kejuruan.

Fitridawati Soehardi, \& Dwi Vita Lestari Soehardi. (2019). Pelatihan Tata Rias Wajah Sehari-Hari Pkk Bukit Bestari Kota Tanjung Pinang. Dinamisia : Jurnal Pengabdian Kepada Masyarakat. https://doi.org/10.31849/dinamisia.v3i0.2944

Noorfitrihana. (2015). IbM Pada Industri Kecil Bidang Busana Sebagai Upaya Peningkatan Kapasitas Produksi dan Manajemenbisnis. http://lppm.uny.ac.id/sites/lppm.uny.ac.id/files/Noor Fitrihana_PPM_IbM.pdf

Nurdhani, Desak Putu Agung, D. D. W. (2016). Teknik Dasar Bordir. Direktorat Pembinaan Kursus dan Pelatihan.

Poespa, G. (2005). Panduan membuat ragam hias motif bordir serta penerapannya. PT. Gramedia Pustaka.

Ramadani, P., \& Novrita, S. Z. (2019). Peningkatan Hasil Belajar Keterampilan Menjahit Rok Melalui Media Mock Up Di Kelas Tata Busana Siswa SLB Negeri 2 Padang. GORGA Jurnal Seni Rupa. https://doi.org/10.24114/gr.v8i1.13170

Sawitri, S. (2018). The implementation of Integrated Entrepreneurship Material on Dress Making Teaching in Vocational High School. AIP Conference Proceedings. https://doi.org/10.1063/1.5028089

Syafri, H. (2007). Konstruksi Pola Busana Wanita. UNP Press. 